\title{
ARTYKUŁY
}

Klio. Czasopismo poświęcone dziejom Polski i powszechnym PL ISSN 1643-8191, t. 26 (3)/2013, s. 141-172

(c) $(1) \odot$

DOI: http://dx.doi.org/10.12775/KLIO.2013.036

Grzegorz Сномicкі

(Kraków)

\section{Podręczniki do historii wobec reform szkolnictwa. Problemy doboru treści}

$S_{\text {uczycielskiego i uczniowskiego wyposażenia, co zawdzięczają swej po- }}^{\text {zkolne podręcziki do historii stanowią }}$ wszechności, uniwersalności i wielofunkcyjności ${ }^{1}$. Przyzwyczailiśmy się do tego, że każdy uczeń powinien mieć podręcznik, który zapewni mu pełnię wiedzy niezbędnej na danym etapie edukacji historycznej. Tradycyjny podręcznik jest względnie tani oraz trwały, nie wymaga dodatkowych urządzeń odtwarzających, nie „traci zasięgu” ani nie „zawiesza się" 2 . Z punktu widze-

${ }^{1}$ J. Hanisz, Podręcznik, [w:] Encyklopedia pedagogiczna XXI wieku, t. 4, red. T. Pilch, Warszawa 2005, s. 461 i n.; M. Bieniek, Dydaktyka historii, wybrane zagadnienia, Olsztyn 2007, s. 72-73; eadem, Podręcznik szkolny historii, [w:] Wspótczesna dydaktyka historii (zarys encyklopedyczny), red. J. Maternicki, Warszawa 2004, s. 266. Niewątpliwe jest obecnie oddziaływanie prac Janusza Skrzypczaka, do którego definicji i systematyki podręczników odwołują się autorzy piszący na ten temat.

${ }^{2}$ E. Chorąży, D. Konieczka-Śliwińska, S. Roszak, Edukacja historyczna w szkole. Teoria i praktyka, Warszawa 2008, s. 163-164; M. Kujawska, Podręcznik obudowany do nauczania i uczenia się historii, [w:] Podręczniki historii - perspektywy modernizacji, red. M. Kujawska, Poznań 1994, s. 55 i n.; B. Urbanowicz, Miejsca i rola podręcznika w procesie 
nia nauczyciela uszczegóławia on i dopełnia zdawkowe zapisy dokumentów programowych. Używając obrazowego porównania - pokrywa różnorodnymi tkankami martwy szkielet programu. Wbrew teorii dydaktycznej może w praktyce dominować nad programem. Pomaga także w sytuacjach kryzysowych, gdy trzeba nadrobić braki powstałe z przyczyn losowych albo usystematyzować lub dopełniać materiał, którego nie udało się przeanalizować podczas lekcji. Zdaniem klasyka polskiej dydaktyki,

nauczanie historii nie może obejść się bez podręcznika, jest nań skazane także i ze względu na charakter przedmiotu, który stawia niemałe wymagania w zakresie pamięciowego opanowania wiedzy ${ }^{3}$.

Wreszcie, według potocznej opinii, podręcznik daje społeczeństwu wgląd w treści nauczania i ich aksjologiczną podbudowę. Czego nauczą się dzieci w szkole? Tego, co mają w książkach - brzmi najprostsza odpowiedź ${ }^{\text {. }}$ Co za tym idzie, oczekiwania wszystkich uczestników i obserwatorów procesów edukacji (nauczycieli, uczniów, rodziców, środowisk uczelnianych i mediów) wobec podręczników są wysokie.

Książki szkolne będą zatem dwojakie: rzeczowe dla uczniów i informacyjne dla nauczycieli, aby umieli dopilnować używania tamtych [...] jedne (zaś) i drugie zwięzłe i metodyczne

edukacji historycznej, [w:] „Historia i spoteczeństwo. Dziedzictwo epok”. Edukacja historyczna w szkole ponadgimnazjalnej po 2013 roku, red. M. Fica, Katowice-Bielsko-Biała 2012, s. 20-21.

${ }^{3}$ J. Maternicki, Trzy typy szkolnego podręcznika historii, [w:] idem, O nowy ksztatt edukacji historycznej, Warszawa 1984, s. 67.

${ }^{4}$ Temu przekonaniu zawdzięczamy liczne opracowania poświęcone analizie treści podręczników szkolnych, jako specyficznemu uzewnętrznieniu stanu historiografii, emanacji wpływów ideologicznych i mechanizmów mentalnościowych (zarówno funkcjonujących podświadomie, jak i sterowanych przez władze lub wpływowe środowiska opiniotwórcze). Tytułem przykładu wypada wymienić przynajmniej cztery książki reprezentatywne dla tego nurtu: Z. Mazur, Obraz Niemiec w polskich podręcznikach szkolnych do nauczania historii 1945-1989, Poznań 1995; J. Ronikier, Mit i historia: mitotwórcze funkcje podręczników szkolnych, Kraków 2002; K. Sanojca, Obraz sąsiadów w szkolnictwie powszechnym Drugiej Rzeczypospolitej, Wrocław 2003; M. Hoszowska, Sita tradycji, presja życia. Kobiety w dawnych podręcznikach dziejów Polski (1775-1918), Rzeszów 2005. 
- pisał Jan Amos Komeński5 . Od tej jakże lapidarnej, a celnej konstatacji zaczęła się nowoczesna refleksja nad podręcznikami, kontynuowana przez wiele pokoleń myślicieli - teoretyków, autorów - praktyków i badaczy empiryków. Z jednej strony powstają nadal prace, w których są analizowane najsubtelniejsze niuanse podręcznikowych komunikatów ${ }^{6}, z$ drugiej zaś, w wielu nowoczesnych i - skądinąd użytecznych - opracowaniach pedagogiczno-dydaktycznych temat zawartości i stosowania podręcznika zanikł niemal zupełnie. Nawet sam termin zostaje wyrugowany z fragmentów poświęconych środkom dydaktycznym, a hasło „podręcznik” nie występuje w indeksie rzeczowym. Na przykład Geoff Petty w obszernej publikacji liczącej 540 stron zaledwie kilka razy zdawkowo wspomina o stosowaniu podręczników w nauczaniu. Czyżby uważał temat za oczywisty i wyczerpany? Najdłuższy passus tej pracy, odnoszący się do podręczników, wymaga zatem zacytowania:

WSPIERANIE PAMIĘCI - PODRĘCZNIK. Jeśli podręcznik w zrozumiały sposób przedstawia wszystkie treści, których nauczasz, może wystarczająco wspierać pamięć twoich uczniów. Jesteś w szczęśliwej sytuacji. Jeśli podręcznik jest zbyt obszerny, powiedz uczniom, które części mogą pominąć lub (jeszcze lepiej) poproś, żeby zaznaczyli, które z nich są istotne dla aktualnego tematu. Jeśli zamierzasz w ten sposób korzystać z podręcznika, poproś uczniów, żeby przynosili go na lekcje i odwołuj się do niego podczas zajęć. Większość nauczycieli nie znajduje podręczników odpowiadających ich potrzebom [wyróż. - G. C.]. Niektórzy wolą, żeby ich uczniowie mieli osobiste notatki ${ }^{7}$.

5 J. A. Komeński, Wielka dydaktyka, Wrocław 1956, s. 223, 315.

${ }^{6}$ Celują w tym zwłaszcza poloniści, a ich dogłębne, ale i wysoce zatomizowane studia przynoszą plon w postaci prac zbiorowych, takich jak np. Podręczniki do ksztatcenia polonistycznego w zreformowanej szkole - koncepcje, funkcje, język, red. H. Synowiec, Kraków 2007. Analityczne badania prowadzone nad treścią podręczników do historii zaowocowały m.in. pracą D. Konieczki-Śliwińskiej, Retoryka we wspótczesnych szkolnych podręcznikach historii, Poznań 2001, a ostatnio artykułami J. Iluka, Czynniki wptywające na przyswajalność wiedzy zawartej w podręcznikach do nauczania historii (część I-II), „Wiadomości Historyczne" 2013, nr 1, s. 11-14, nr 2, s. 19-23.

${ }^{7}$ G. Petty, Nowoczesne nauczanie. Praktyczne wskazówki i techniki dla nauczycieli, wyktadowców i szkoleniowców, przeł. J. Bartosik, Sopot 2010, s. 190-191; równie wymownie na s. 268 (rozdział „Czytanie a uczenie się”): „Badania pokazały, że studenci, którzy 
Zgodnie z tym ostatnim twierdzeniem brytyjskiego pedagoga można i w Polsce zaobserwować grupę praktyków nauczania historii, którzy twierdzą, że używanie podręczników nie jest konieczne, a nawet z pewnych powodów jest niepożądane. Utrzymują oni, że bazowanie na podręczniku zubaża metodyczną inwencję nauczyciela i obniża jego skłonność do uaktualniania własnej wiedzy merytorycznej. Są także nauczyciele „kapryśni”, których nie zadowala żaden z podręczników oferowanych przez wydawców i sądzą, że doskonale obejdą się bez tego środka dydaktycznego. Na ogół taka postawa wywołuje skutek przeciwny do zamierzonego: co ambitniejsi uczniowie, żeby podołać wymaganiom, intensywnie notują, a nawet wymieniają między sobą notatki z wykładów swego mistrza (lub mistrzyni). Jeśli i to nie wystarcza, sięgają oni do kompendiów typu „wszystko, co potrzebne do matury, powtórzysz w dwa dni i zdasz najlepiej pod Słońcem”. Te zaś nie rozwijają ani umiejętności warsztatowych i bardziej subtelnych sprawności myślowych, ani też kultury historycznej, gdyż zawierają głównie schematyczne i niekiedy skażone błędami zestawienia faktów i regułek do bezrefleksyjnego przyswojenia. Zaletą tych publikacji, zapełniających stoiska księgarskie, bywa pomysłowa strukturyzacja wiadomości, ułatwiająca ich szybsze i trwalsze zapamiętanie.

Wykluczając stanowiska skrajne, wypada uznać, że świadomy nauczyciel uczyni z podręcznika ważny, jakkolwiek niedominujący element swego warsztatu $^{8}$ - wykorzysta jego mocne, a zneutralizuje słabe strony, ćwicząc przy tym metody pracy z tekstem i innymi komponentami (jak źródła, mapy, ikonografia, tablice, indeksy), żeby przygotować absolwentów do kształcenia wyższego i ustawicznego, polegającego głównie na samodzielnym studiowaniu coraz trudniejszych książek.

Rzeczywista wartość podręcznika [...] zależy nie tylko od tego, co i w jaki sposób zostało w nim przedstawione, ale również od tego, jak się nim posłużono $[\ldots]^{9}$.

zostali zapisani na kurs, otrzymali podręcznik i przygotowywali się sami, poradzili sobie równie dobrze jak ich koledzy, którzy chodzili na wykłady”.

8 Takie zalecenia formułował już przed półwieczem T. Słowikowski, Metodyka nauczania historii. Podręcznik dla studium nauczycielskiego, Warszawa 1967, s. 146.

${ }^{9}$ E. Chorąży, D. Konieczka-Śliwińska, S. Roszak, op. cit., s. 170. 
Ponadto w czasach, gdy dyscyplina i frekwencja na lekcjach nie są mocną stroną naszych szkół, a wielu uczniów, którzy dawniej, ze względu na stan zdrowia, znajdowali się poza systemem szkolnym, uczestniczy w zajęciach, ale czyni to nieregularnie, nie należy rezygnować ze stosowania podręczników do danego przedmiotu.

Konstrukcja podręcznika do historii powinna umożliwić optymalną realizację następujących funkcji ${ }^{10}$ :

- informacyjnej (dostarczenie podstawowej, dobrze zweryfikowanej i aktualnej wiedzy historycznej);

- metodologicznej (kształtowanie wyobrażeń o przebiegu procesów historycznych i typach narracji);

- badawczej (przygotowanie do rozwiązywania problemów, rozwijanie umiejętności warsztatowych);

- transformacyjnej (przetwarzanie i stosowanie zdobytej wiedzy w praktyce);

- samokształceniowej (rozwój intelektualny i kształtowanie umiejętności samodzielnego pogłębiania wiedzy);

- autokontrolnej (indywidualne badanie własnych osiagnnięć edukacyjnych);

- wychowawczej (wskazywanie pozytywnych wzorców osobowych, formowanie postaw i systemów etycznych);

- motywacyjnej (rozbudzanie ciekawości i pogłębianie zainteresowań historią, dostrzeganie jej użyteczności);

- estetycznej (ukazanie kanonów estetycznych minionych epok; gustowna forma edytorska samej książki).

${ }^{10}$ Alojzy Zielecki szeroko rozbudował hierarchiczny system strukturalny funkcji podręcznika do historii; z jego systematyką powinni zapoznać się potencjalni autorzy podręczników i poświęcić jej chwilę głębokiej refleksji. A. Zielecki, Role i funkcje podręcznika historii, Rzeszów 1984, s. 38-53; bardzo szczegółowo streszcza tę koncepcję B. Urbanowicz, op. cit., s. 22-30. Akceptując poglądy Zieleckiego, podajemy tu zredukowany katalog funkcji, będący modyfikacją koncepcji Jerzego Maternickiego: J. Maternicki, A. Suchoński, C. Majorek, Dydaktyka historii, Warszawa 1993 s. 344-345; problem ten jest podobnie ujęty w nowym podręczniku dydaktyki historii: E. Chorąży, D. KonieczkaŚliwińska, S. Roszak, op. cit., s. 163; Jadwiga Hanisz (op. cit., s. 464) podaje ponadto zbliżone katalogi funkcji według L. Lei, Wincentego Okonia i Czesława Kupisiewicza. 
Dodatkowa funkcja, zwana metodyczną, dotyczy tych nauczycieli, którzy ulegają (mniej lub bardziej świadomie) sugerowanym przez podręcznik celom i metodom nauczania, sposobom utrwalania wiedzy i kontroli osiągnięć. Ugruntowaniu takiej postawy sprzyja tworzenie multimedialnych pakietów, w których podręcznik zajmuje jeszcze miejsce centralne, ale mogących zawierać nawet kilkanaście pomniejszych publikacji, przez co nauczyciele otrzymują gotowe rozwiązania metodyczne. Najczęściej jednak podporządkowują się oni merytorycznej zawartości podręcznika. Zauważalne jest więc jego funkcjonowanie w roli nieformalnego programu nauczania ${ }^{11}$. Po reformie z 1999 r. krążyły pogłoski, jakoby niektóre wydawnictwa zupełnie lekceważyły drukowane przez siebie programy, przywiązując wagę tylko do treści podręczników. Obecnie również Ministerstwo Edukacji Narodowej zdaje się podnosić rangę podręczników pośród innych elementów systemu kształcenia, gdyż już tylko one podlegają zewnętrznej ocenie recenzentów i przechodzą procedurę centralnego, ministerialnego zatwierdzania $^{12}$.

Dydaktycy i najambitniejsi (pod względem metodycznym) nauczyciele oczekują, że podręcznik zachęci uczniów do samodzielnych refleksji, do stawiania pytań i analizowania problemów, do formułowania własnych ocen w kwestiach dyskusyjnych ${ }^{13}$. Pozytywnie oceniają oni podręczniki zaopatrzone w liczne ćwiczenia, zadania o charakterze problemowym, obszerne bloki analiz źródłowych. Nowoczesny podręcznik miałby więc kształtować umiejętności i sterować pracą opartą na strategii wielostronnego nauczania oraz uczenia się historii: przez poznawanie, odkrywanie, działanie i przeży-

${ }^{11}$ J. Rohlfes, Środki dydaktyczne nauczania i uczenia się historii, przeł. A. Buk, [w:] Nowe drogi w nauczaniu historii. Wspótczesna dydaktyka niemiecka, red. J. Centkowski i et al., Rzeszów 1999, s. 207.

12 Przedmiotowe programy nauczania są obecnie aprobowane do realizacji na poziomie rady pedagogicznej i dyrekcji szkoły, które ponoszą odpowiedzialność za ich zgodność z Podstawa programową, poza jakąkolwiek kontrolą publikuje się także materiały pomocnicze i środki dydaktyczne, np. atlasy.

13 J. Maternicki, Szkolne podręczniki historii - problemy i perspektywy modernizacji, [w:] idem, Edukacja historyczna mtodzieży. Problemy i kontrowersje u progu XXI wieku, Toruń 1998, s. 129-131. 
wanie $^{14}$. Inne są natomiast oczekiwania uczniów, których zadowala przejrzyście podana i zrozumiała wiedza w zakresie niezbędnym do uzyskania pozytywnych ocen. Komunikatywność, poręczność i niewielkie gabaryty książki - to największe zalety z punktu widzenia młodego odbiorcy. Mamy więc do czynienia $\mathrm{z}$ dwoma wizjami: $\mathrm{z}$ jednej strony podręcznika uniwersalnego, z bogatą obudową, nastawionego na kompleksową realizację funkcji kształceniowych, a z drugiej „cienkiego” kompendium z niezbędnymi treściami merytorycznymi - faktycznej „pamięciowej podpórki”, o jakiej wspominał Geoff Petty. Kolizja oczekiwań, a zwłaszcza smutna konstatacja, że znaczna część młodzieży szkolnej niezbyt gorliwie korzysta ze swoich pięknych i obszernych podręczników, zdaje się skłaniać ku jeszcze bardziej starannemu selekcjonowaniu i strukturyzowaniu ich zawartości ${ }^{15}$.

Fundamentalnym problemem szkolnej edukacji historycznej pozostają bowiem: selekcja, hierarchizacja i usystematyzowanie materiału rzeczowego. Permanentne reformy systemowo-programowe sprawiają, że każda koncepcja opracowana w tej dziedzinie po kilku latach musi ulec poważnej rewizji lub całkowicie upada. Po 1999 r., gdy cykle kształcenia uległy skróceniu, nie sprawdził się zamysł autorów ówczesnej Podstawy programowej, polegający na zamknięciu kompletnego, liniowego kursu chronologicznego na etapie gimnazjalnym i wprowadzaniu w liceach programów systematyzujących materiał według zasad problemowo-przekrojowych. Nie zawsze w gimnazjach udawało się w pełni zrealizować program ${ }^{16}$, a wiedza absolwentów okazywała się niewystarczająca do operatywnego posłużenia się nią na wyższym poziomie abstrakcji i syntezy problemowej. Po pierwszych, negatywnych doświadczeniach, nauczyciele licealni porzucili więc nowa-

${ }^{14}$ Tego rodzaju dążenia obecne są także w refleksji nad podręcznikami polonistycznymi, por.: Z. Uryga, Miejsce dyskursu o metodzie w licealnych podręcznikach literatury, [w:] Podręczniki do ksztatcenia polonistycznego..., s. 82-84.

15 Być może lepiej byłoby opracować dla nauczycieli (jak radził Jan Amos Komeński) odrębne książki, w których byłoby miejsce na merytoryczne rozszerzenia i dodatkowe materiały stosowane zależnie od indywidualnych potrzeb. Niedogodności wypływające z użytkowania przez nauczyciela i ucznia tej samej książki dostrzega również w przypadku polonistyki J. Kowalikowa, Podręcznik szkolny z perspektywy autora, [w:] ibidem, s. 77.

${ }^{16}$ Pośród przyczyn tego stanu rzeczy należałoby wskazać na drastyczny spadek efektywności nauczania w III klasie po przeprowadzeniu egzaminu gimnazjalnego. 
torskie programy i podręczniki, powracając do tradycyjnego przerabiania „od nowa” kolejnych epok zgodnie z ich następstwem. W porównaniu $\mathrm{z}$ nauką $\mathrm{w}$ czteroletnim liceum mieli jednak na to znacznie mniej czasu. Według powszechnej opinii ucierpiała na tym jakość nauczania. Niestety nie przeprowadzono badań, które ukazałyby ten problem w sposób pełny i zobiektywizowany. Dalsze podnoszenie stopnia skolaryzacji młodzieży, przy jednoczesnym załamywaniu się potencjału demograficznego, przyniosło nowe zjawiska. Do szkół kończących się maturą zawitał spory odsetek uczniów o mniejszych uzdolnieniach i/lub niskiej motywacji do nauki ${ }^{17}$. Właśnie to z całą mocą uświadomiło starą skądinąd prawdę: nawet liceum ogólnokształcące nie jest w stanie nauczyć wszystkich wszystkiego w maksymalnym zakresie. Ponadto młodzież, coraz bardziej przekonana o swej wysokiej (podmiotowej) ${ }^{18}$ pozycji w szkole, zaczęła skutecznie stawiać opór tradycyjnemu materializmowi dydaktycznemu, niezależnie od postaci w jakiej występował ${ }^{19}$. Wielu uczniów, poprzestając na promocji uzyskiwanej dzięki ocenom dopuszczającym i krzepiącej perspektywie zdania matury na poziomie podstawowym z wynikiem nieznacznie przekraczającym trzydziestoprocentowe minimum, nie uczy się niczego ponad to, co do pokonania

17 Oszacowanie motywacji, jej wpływ na efekty kształcenia oraz kształtowanie właściwych motywacji należy do złożonych problemów pogranicza psychologii i dydaktyki. Podkreślając znaczenie postawy i osobowości nauczyciela jako czynników motywujących, warto zauważyć, że nauczyciel sfrustrowany własną sytuacją, wyczerpany emocjonalnie (w tym przypadku mam na myśli nasilającą się presję zewnętrzną zmierzającą do zachwiania stabilności i obniżenia prestiżu nauczycieli), nie będzie w stanie rozbudzać i pielęgnować aspiracji uczniów, ci zaś, zdając sobie sprawę z kryzysu i bezrobocia wśród wykształconej młodzieży, będą odporni na pozytywne wzmocnienia ze strony szkoły, por.: E. Lisowska, Rozpoznawanie i przewidywanie wypalenia zawodowego nauczycieli. Studium pedagogiczne, Kielce 2012, s. 62-71; S. Korczyński, Motywowanie uczniów do skutecznej nauki, [w:] Nauczyciel i uczeń w zreformowanej szkole, red. S. Korczyński, Opole 2006.

${ }^{18}$ E. Kubiak-Jurecka, Podmiotowość w wychowaniu a demokratyzacja stosunków edukacyjnych-szanse, ograniczenia, bariery, [w:] Nauczyciel-uczeń: między przemoca a dialogiem - obszary napięć i typy interakcji, red. M. Budzikowa, Kraków 1996, s. 35; W. Komar, „Wojna” w edukacji: stosunki nauczyciel-uczeń. Pejzaże "walki” i nadziei, [w:] ibidem, s. 139.

19 Rozważania na temat wzajemnego stosunku pomiędzy wymaganiami, celami a materiałem nauczania przeprowadził m.in. B. Niemierko, Cele ksztatcenia, [w:] Sztuka nauczania. Czynności nauczyciela, red. K. Kruszewski, Warszawa 1995, s. 28 i n. 
tych progów jest absolutnie niezbędne. Wobec takiej postawy zarówno nauczyciele, jak i rodzice czy opiekunowie, a nawet decydenci zarządzający naborem na następny (wyższy, w tym również akademicki) etap edukacji pozostają $\mathrm{w}$ zasadzie bezradni ${ }^{20}$. W niektórych oficjalnych enuncjacjach wprost mówi się o tym, że upowszechnienie edukacji jest priorytetową wartością, dla której trzeba poświęcić jej (tradycyjnie rozumiany) wysoki poziom.

Reakcją Ministerstwa Edukacji Narodowej ${ }^{21}$ stało się wprowadzenie nowej Podstawy programowej, według której cezurę końcową gimnazjalnego kursu historii stanowi 1918 r., a nauczanie dziejów najnowszych zostaje przeniesione do pierwszej klasy szkoły ponadgimnazjalnej. W klasach II i III liceum młodzież ma uczęszczać już do klas o wyraźnym profilu. W tym miejscu nie zajmiemy się potencjalnymi zaletami i wadami tych rozwiązań. Niewątpliwie zdezorganizowały one nauczanie w liceach i zmusiły do ponownego (i być może ponownie jałowego) wysiłku dostosowywania się do zmienionych dyrektyw, podczas gdy sensem aktywności pedagogicznej jest skupienie się przede wszystkim na wychowankach, a nie na ustawicznie

20 Współczesne trendy teorii oceniania, zarówno w kontekście skuteczności edukacji (wysokich osiągnięć), jak i rozwoju emocjonalnego, postaw oraz motywacji młodzieży przedstawił B. Niemierko, Między prawdą a skutecznościa - perspektywy oceniania szkolnego, [w:] Teraźniejszość i przysztość oceniania szkolnego, red. B. Niemierko, M. K. Szmigiel, Kraków 2010, s. 37-55. Konkluzje autora zmierzają ku preferowaniu prorozwojowych form oceniania, przy jednoczesnym uwydatnianiu wysoce prawdopodobnej rozbieżności pomiędzy „oceną kształtującą”, przy pomocy której nauczyciel stara się stymulować rozwój ucznia, a rezultatem „oceniania sumującego” osiągnięcia tegoż ucznia (tzn. wynikiem końcowego egzaminu). Wydaje się jednak, że kluczowi uczestnicy procesów edukacyjnych nie są przygotowani do zrozumienia tej dysharmonii; dotyczy to zwłaszcza decydentów, którzy na podstawie powierzchownej interpretacji surowego wyniku egzaminu zewnętrznego gotowi są oceniać pracę szkoły, a nawet decydować o jej likwidacji, „bo jest słaba”.

${ }^{21}$ Dążenia do zmiany Podstawy programowej z 1999 r. mają kilkuletnią historię. Instytut Spraw Publicznych wykonał krytyczne ekspertyzy, które podsumował Krzysztof Konarzewski w publikacji Reforma oświaty. Podstawa programowa i warunki ksztatcenia, Warszawa 2004. Wkrótce też (2005) zespół powołany przez ISP na zlecenie MEN-u opracował i opublikował projekt nowej Podstawy programowej, który jednak nie został wdrożony. 
zmienianych wytycznych ${ }^{22}$. Od nowa przyszło także opracowywać, wydawać, zatwierdzać, wybierać i oceniać podręczniki.

Aby ocenić funkcje informacyjne podręcznika, trzeba sprawdzić, czy zasób elementów użytych do budowy wyobrażeń o przeszłości jest wystarczający, a przy tym nie przerasta możliwości percepcyjnych młodzieży. Nie należy tracić też z widoku funkcji metodologicznych, badawczych i warsztatowych, które przygotowują do śledzenia i rozumienia życia społecznego (minionego, ale i obecnego), czyli dochodzenia do pewnych ustaleń oraz wniosków drogą krytykowania źródeł, poprawnego rozumowania i tworzenia narracji własnej na jego temat. Tych funkcji nie da się realizować w faktograficznej pustce - aby wznosić śmiałe konstrukcje, trzeba mieć odpowiednią liczbę pasujących do siebie klocków. Wnioskowania oparte na nikłych przesłankach są zazwyczaj prymitywne albo zgoła wiodą na manowce.

Czy istnieją obiektywne kryteria ważności poszczególnych informacji, czy decydują o niej subiektywne odczucia historyków? ${ }^{23}$ Naszym zdaniem główne kryterium powinna stanowić ciągłość zjawisk we współczesnej kulturze i rzeczywistości społecznej oraz ich obecność wśród używanych kodów i akceptowanych systemów wartości. Gdy wyznaczamy nauczaniu enkulturacyjne zadania, pojawia się pytanie o kanon wiedzy niezbędnej do odczytywania komunikatów zbudowanych ze słów i innych znaków zakotwiczonych w przeszłości. Szeroko pojęta edukacja historyczna jest najważniejszą z dróg prowadzących do rozumienia języka (również niewerbalnego) epok minionych. Bez głębszej erudycji pozostaje tylko ślizganie się receptorów po tajemniczych symbolach a w dalszej kolejności - zerwanie ciągłości komunikacyjnej, gdyż zapewniające ją kanały stają się niedrożne.

${ }^{22}$ Kulturową niespójność oraz niejednoznaczne, a częstokroć postrzegane jako negatywne, skutki społeczne reform oświatowych przeforsowanych w Polsce po 1989 r. w pesymistycznym tonie omówili prelegenci inaugurujący XVI Krajową Konferencję Diagnostyki Edukacyjnej w Toruniu: Z. Kwieciński, Zmiany w edukacji - próba bilansu dwóch dekad; D. Klus-Stańska, Ukryta polityczność oceniania szkolnego w świetle radykalnych nurtów socjologicznych - tezy do wystąpienia; obydwa teksty, [w:] Teraźniejszość i przysztość oceniania..., s. 23-33.

${ }^{23}$ Krzysztof Kruszewski przedstawił problem kryteriów doboru materiału nauczania z punktu widzenia rozmaitych tendencji dydaktyki ogólnej: K. Kruszewski, Program szkolny, [w:] Sztuka nauczania. Szkota, red. K. Konarzewski, Warszawa 1995, s. 191 i n. 
Kwestia liczby i doboru pojęć oraz zjawisk składających się na wyobrażenia umożliwiające rozumienie przeszłości wciąż powraca jako ważkie zagadnienie rzutujące na celowość nauczania naszego przedmiotu. Gdy język powszedniego porozumiewania się młodzieży jest coraz uboższy, a środki współczesnej komunikacji odrywają się od tradycji historycznej i literackiej, pytania te zaczynają brzmieć dramatycznie, gdyż niedobory leksykalne i deficyty kulturowe uczniów stają się już zbyt dotkliwe, by szkolna historia, wciąż okrawana i o stale obniżającym się prestiżu w hierarchii przedmiotów nauczania, mogła je zrekompensować ${ }^{24}$.

Obok pytania o kanon (trudny zresztą do ustalenia) pojawia się również pytanie o kontekst, w jakim postacie i zjawiska miałyby się utrwalać w historycznej świadomości. Właściwe zrozumienie pojęć lub symboli także wymaga interpretowania ich w szerszych kontekstach i odniesieniach do realiów epoki oraz specyfiki konkretnych wydarzeń. Jak twierdzi Adam Suchoński, aktualne prądy w tym zakresie odzwierciedlają zalecenia Międzynarodowego Stowarzyszenia Dydaktyków Historii, które postuluje, by w podręcznikach nowych generacji:

- ograniczać wątki polityczne,

- rozbudowywać wątki kulturowe,

- rekonstruować przeszłość przez pryzmat życia codziennego ludzi różnych epok,

- koncentrować się na tym, co w przeszłości łączyło państwa i społeczeństwa, nie zaś na odmiennościach,

- ukazywać rolę kobiet w społeczeństwie,

${ }^{24}$ Jolanta Nocoń ukazuje (cytując argumenty użyte w ważkich dyskusjach nad reformowaniem polskiej edukacji) fundamentalne przeciwstawienie „tradycyjnego” modelu „kształcenia erudytów” - przez zdyscyplinowany przekaz - i „nowoczesnego” modelu całościowego rozwoju ucznia, gdzie zmiany w jego „strukturach wiedzy” schodzą na dalszy plan wobec uwolnienia potencjału osobowościowego i nabywania kompetencji. Ponieważ termin „erudycja” wiąże się z tradycjonalizmem, pragnę podkreślić, że chodzi mi właśnie o rozwinięcie kompetencji komunikacyjnych oraz osobowości uczniów i uwrażliwienie ich na dziedzictwo kulturowe, nie zaś o wyuczenie wielu faktów i poznanie historii dla niej samej. Nie potrafię jednak rozwikłać dylematu zawartego w paradoksalnym pytaniu: ile można (nowocześnie) umieć - niczego (tradycyjnie) nie wiedząc? Por.: J. Nocoń, Podręcznik szkolny $w$ dyskursie dydaktycznym - tradycja i zmiana, Opole 2009, s. 30. 
- akcentować problemy ekologiczne,

- kształtować świadomość regionalną, narodową i europejską,

- nawiązywać do historycznych korzeni współczesnych procesów integracyjnych,

- zauważać sprawy kontrowersyjne i wydarzenia pozwalające zrozumieć źródła problemów współczesności ${ }^{25}$.

Pogodzenie tych szczytnych zaleceń z oczekiwaniami miejscowych społeczeństw jako dysponentów oświaty w poszczególnych krajach ${ }^{26}$, z realnymi możliwościami szkoły jako instytucji prowadzącej kształcenie pośród rozmaitych ograniczeń i barier oraz z chłonnością intelektualną i wytrzymałością emocjonalną uczniów nie jest proste, a - jak już wyżej sygnalizowaliśmy - być może w ogóle nie jest możliwe.

U schyłku lat dziewięćdziesiątych XX w. Małgorzata Pawlak i Karol Sanojca zbadali faktografię służącą do opisu Wiosny Ludów ${ }^{27}$, układając zestaw 83 wydarzeń złożonych z ponad 130 pojedynczych elementów występujących w podręcznikach akademickich (były to nazwiska, daty-fakty, miejsca-terminy geograficzne, inne imiona własne). Studentom polecono odrzucić z zestawu to, co uznali za nieistotne, a raczej zbyt szczegółowe dla uczniów w wieku 13-14 lat (ówczesna klasa VII szkoły podstawowej). Okazało się, że zdaniem studentów bez użycia (średnio) 11 nazwisk nie uda się opisać Wiosny Ludów. Prawie 80\% kandydatów na nauczycieli wybierało zestaw złożony z ponad 30 wydarzeń, ostatecznie wynik średni

25 A. Suchoński, Unia Lubelska 1569 roku w świetle wspótczesnych tendencji w pisarstwie podręcznikowym, [w:] Wokót problemów edukacji. Księga pamiątkowa dedykowana Pani Profesor Grażynie Pańko, red. J. Wojdon, B. Techmańska, Wrocław 2012, s. 189.

${ }^{26}$ Niepokojących, z naszego punktu widzenia, spostrzeżeń dokonała B. Knapiak, "Kraj, który byt blisko Zachodu”-Polska we francuskich podręcznikach do nauczania historii, „Wiadomości Historyczne” 2013, nr 3, s. 27-36. Z ustaleń autorki wynika, że elementy historii Polski, a nawet szerzej - całego regionu „postsowieckiej” Europy ŚrodkowoWschodniej zniknęły, na skutek podjętych ostatnio reform, z podręczników francuskich, w których rozbudowano za to wątki lokalne i narodowe lub bardziej atrakcyjne i aktualne problemy odległych, ale mających globalny potencjał i znaczenie regionów świata.

${ }^{27}$ M. Pawlak, K. Sanojca, Stare dylematy $w$ nowej rzeczywistości - mtody nauczyciel wobec problemu selekcji materiatu historycznego, [w:] Edukacja historyczna $w$ reformowanej szkole. Zatożenia metodyczne, red. A. Zielecki, Kraków 2000, s. 97-107; warto skonfrontować te badania z podobnymi spostrzeżeniami B. Niemierki, op. cit., s. 34 i n. 
dla grupy wynosił aż 42 wydarzenia. Wyrażało się w tym przekonanie (nie w pełni świadome), że wyłącznie dzięki odpowiedniemu zagęszczeniu faktografii, nawet informacjami trzeciorzędnymi ${ }^{28}$, uda się odpowiednio naświetlić ważny moment dziejowy. Eksperymentatorzy dostrzegli także wielkie zróżnicowanie rangi dobieranych faktów. Niektórzy studenci pomijali likwidację pańszczyzny i uwłaszczenie w monarchii Habsburgów lub procesy powiązane $\mathrm{z}$ innymi sferami niż klasyczna historia polityczno-militarna. Wysiłki organizacyjne Adama Mickiewicza (marginalne dla przebiegu walk, ale pokazujące trwałość idei legionowej Jana Henryka Dąbrowskiego i aktywność polskiej emigracji) zdaniem większości studentów były nieistotne. Być może dlatego, że Wieszcz to „postać z innego przedmiotu”? Przeanalizowano także odpowiednie rozdziały z kilku podręczników dla klasy VII, używanych wówczas w szkołach podstawowych. Okazało się, że do opisu Wiosny Ludów autorzy potrzebowali od 22 do 53 informacji faktograficznych. Najbardziej zwięzły spośród analizowanych podręczników nie zyskał szerszego zastosowania w praktyce szkolnej, gdyż zarzucano mu, że jest w nim zbyt mało merytorycznej zawartości. Była to zaś książka dopracowana, charakteryzująca się jasnym wykładem i precyzyjnym osnuciem narracji na informacjach pierwszoplanowych. Pominięcie zatem wielu szczegółów nie uniemożliwiało zrozumienia przebiegu wypadków i ich powiązań przyczynowo-skutkowych.

Ważnym zadaniem autorów podręczników jest określenie celu, któremu ma służyć każdy akapit - aby kreował obraz problemu czy epoki według pewnej myśli przewodniej. Skoro zaś Wiosna Ludów to okres:

- walk o niepodległość narodów uciemiężonych pod obcym zaborem;

- walk narodowych o powstanie zjednoczonego państwa;

- walk o swobody obywatelskie i demokratyzację ustroju;

- walk socjalnych o równość społeczną, mających podłoże ekonomiczne;

- wewnętrznej i zewnętrznej reakcji przeciwko tym ruchom (w myśl zasad Świętego Przymierza);

${ }^{28}$ C. Nowarski, Problem btędów dydaktycznych $w$ pracy nauczyciela historii, „Wiadomości Historyczne” 1991, nr 1, s. 41-47; autor nazywa taką postawę „kultem faktu historycznego”. 
należy te sprawy egzemplifikować, pieczołowicie dobierając reprezentatywne zjawiska i postacie, ewentualnie oszczędnie uzupełnić je o fakty dopełniające, pozwalające ubarwić i uplastycznić opowieść. To jednak wciąż ogólne wskazania i zgodne z nimi konkretne rozwiązania mogą się okazać zdumiewająco zróżnicowane.

Według teorii dydaktycznej, program definiuje główne kryteria doboru treści nauczania, podręcznik zaś powinien pozostawać w zgodności z jego wskazaniami ${ }^{29}$. Obecnie Podstawa programowa ksztatcenia ogólnego, będąc nadrzędną dyrektywą dla wszystkich uczestników procesu edukacji, decyduje o tym, co powinny zawierać podręczniki. Podstawe programowa sformułowano jako dokument stosunkowo zwarty, zaledwie sygnalizując w niej konieczne treści. Ministerstwo zapewniało jednak, że stworzyło precyzyjne wytyczne, dokładnie instruujące, czego należy nauczać i co stanie się przedmiotem egzaminowania. Podręcznika nie da się ocenić przez mierzenie osiągnięć używających go uczniów, gdyż zależą one nie tylko od niego, lecz także od ich środowiskowych oraz osobistych uwarunkowań ${ }^{30}$. Podręczniki nie są przecież (jak to już wyżej zaznaczono) samoistnie skutecznymi samouczkami. Analizując kilka przykładowych zapisów Podstawy programowej $^{31}$, zobaczymy, że jej zalecenia dla autorów podręczników są $\mathrm{w}$ istocie bardzo enigmatyczne, bowiem wbrew zapowiedziom dokument ten wcale nie określa zasobu wiedzy, którą powinni opanować absolwenci poszczególnych klas i typów szkół. Odwołując się do teorii dydaktycznej, autorzy Podstawy programowej deklarują zerwanie z encyklopedyzmem ${ }^{32}$. Uczeń nie zdoła jednak rozwinąć umiejętności wyższego stopnia, nie posługując się informacjami oraz pojęciami i nie wyrabiając sobie systemu

${ }^{29}$ E. Chorąży, D. Konieczka-Śliwińska, S. Roszak, op. cit., s. 168.

30 Zjawiska te Nocoń, opisując „konteksty dyskursu dydaktycznego”, zaliczyła do „lokalnego kontekstu procesu nauczania-uczenia się”, podczas gdy modele kształcenia i programy edukacyjne umieściła na wyższym poziomie „kontekstów psychopedagogicznych", J. Nocoń, op. cit., s. 27-28.

${ }^{31}$ Dalsze odwołania według: Rozporządzenie MEN z dnia 23 grudnia 2008 r. w sprawie podstawy programowej wychowania przedszkolnego oraz kształcenia ogólnego w poszczególnych typach szkół, Załączniki nr 2 i nr 4, Dz.U. Nr 4, poz. 17, s. 198 i n.

32 Podstawa programowa z komentarzami, t. 4: Edukacja historyczna i obywatelska w szkole podstawowej, gimnazjum i liceum, MEN, [b.m., b.r.], s. 78. 
adekwatnych wyobrażeń. Mniej istotne, czy zapamięta on dokładną datę bitwy grunwaldzkiej (wypada ją znać, gdyż głęboko zakorzeniła się w polskiej tradycji), powinien natomiast umieszczać to wydarzenie we właściwym przedziale czasu (przełom XIV i XV w., początki unii polsko-litewskiej, panowanie Władysława Jagiełły, schyłek rycerskiego średniowiecza), lokalizować tereny, na których toczyły się zmagania i - mając na uwadze ich geopolityczne położenie, stosunki społeczne, a także i środowisko przyrodnicze - rozpoznać powody konfliktu oraz rozmaite uwarunkowania rzutujące na jego przebieg i rezultaty. Aby przeprowadzać poprawne rozumowania i wyciągać słuszne wnioski, należy także zdawać sobie sprawę ze specyfiki instytucji świata feudalnego, takich jak zakon rycerski, pospolite ruszenie, wojsko zaciężne itp. Przede wszystkim zaś niezbędna jest znajomość terminologii i symboliki pozwalających odczytać komunikaty („teksty kultury”) mówiące o bitwie grunwaldzkiej i skonstruować własną wypowiedź (w szkole podstawowej np. rysunek, w gimnazjum, dajmy na to - rocznicową prezentację lub poster, na maturze - esej) na jej temat. Sztuka polega na wyważeniu ilości i jakości treści odpowiadających celom, przyświecającym danemu etapowi edukacji. Dobranie faktografii i środków tekstowo-wizualnych ${ }^{33}$ do zamierzonych wyników, tak by tworzyły merytorycznie poprawny i dydaktycznie spójny system, jest sztuką wymagającą albo wielkiego talentu, albo głębokiej refleksji i żmudnego trudu. Dlatego niedowierzanie budziły wielokrotnie powtórzone obietnice, że nowa Podstawa programowa precyzyjnie określi, czego szkoła jest zobowiązana nauczyć ucznia o przeciętnych uzdolnieniach ${ }^{34}$, poprzez opisy treści i umiejętności w języku wymagań szczegółowych ${ }^{35}$, stanowiące równocześnie standardy egzaminacyjne (wyróż. - G. C).

Przypatrzmy się, mając w pamięci jubileusz z 2010 r., jakie instrukcje dano autorom podręczników (a także egzaminatorom) w sprawie bitwy grunwaldzkiej i - szerzej - stosunków polsko-krzyżackich. Jest to materiał

$33 \mathrm{~W}$ wielu przypadkach celowe byłoby także posłużeni się dźwiękiem. Melodie hymnów, pieśni patriotycznych i innych utworów muzycznych są również bardzo istotnym nośnikiem powiązanych z nimi skojarzeń.

34 Podstawa programowa z komentarzami..., s. 10.

35 Ibidem, s. 22. 
niezwykle silnie zakorzeniony w tradycji ${ }^{36}$, którego nie pomijano w nauczaniu dziejów ojczystych, oczywiście w czasach, gdy decyzja w tej sprawie była w miarę suwerennie podejmowana przez władze, kierujące edukacją historyczną polskiej młodzieży według sobie właściwych kryteriów ideowych ${ }^{37}$.

W szkole podstawowej wymagania ogólne w punkcie I stanowią, że „uczeń [...] przyporządkowuje fakty historyczne datom”. Efekt procesu nauczania-uczenia się historii polega m.in. na tym, że jego podmiot zachowuje w pamięci datowane fakty. Ile ich jednak potrzeba w konkretnych wypadkach? Rozpatrzmy zapis punktu 17.4 mówiący: „[uczeń] opowiada o przyczynach i skutkach bitwy pod Grunwaldem”. Zapis ten nie informuje o merytorycznym szkielecie „opowiadania”. „Opowieścią” na ten temat jest obszerna monografia Stefana M. Kuczyńskiego o wielkiej wojnie z zakonem $^{38}$, jak i znacznie przystępniejsze publikacje popularne ${ }^{39}$ czy rozlicz-

$36 \mathrm{Na}$ podstawie badań ankietowych prowadzonych wśród młodzieży szkolnej w latach 1975-1990 Janusz Rulka ustalił niezachwianie pierwszą pozycję Grunwaldu jako najchwalebniejszego wydarzenia w dziejach Polski, absolutną dominację Krzyżaków Henryka Sienkiewicza wśród znanych (lubianych) książek historycznych i podobną przewagę Krzyżaków Aleksandra Forda nad innymi filmami historycznymi (badacz nie uwzględniał faktu, że dzieła te należały do ówczesnego obowiązkowego kanonu szkolnych tekstów kultury) oraz bardzo wysoką pozycję Władysława Jagiełły w rankingu wybitnych Polaków (sic!), zob.: J. Rulka, Przemiany świadomości historycznej mtodzieży, Bydgoszcz 1991, passim.

37 Przegląd rozmaitych ujęć tej tematyki począwszy od drugiej połowy XIX w. przedstawiła ostatnio A. Chłosta-Sikorska, Bitwa pod Grunwaldem w polskich podręcznikach do historii, [w:] Bitwa pod Grunwaldem $w$ historii i tradycji Polski i Litwy, red. J. Rajman, Kraków 2011, s. 147-169. Autorka koncentrowała się na zmienności stosowanych figur retorycznych, warstwie semantycznej i semiologii, świadczących o przemianach świadomościowo-ideologicznych i politycznych, oraz mitotwórczym wpływie tradycji grunwaldzkiej w jej ujęciu podręcznikowym. Zob. także: Z. Mazur, op. cit., s. 125-128, gdzie autor wykazał wyraźną i znamienną fluktuację ideologicznej wymowy komunikatów podręcznikowych o starciu grunwaldzkim.

38 S. M. Kuczyński, Wielka wojna z zakonem krzyżackim w latach 1409-1411, Warszawa 1966. Dzieło to, monumentalne, choć już przestarzałe, wspominamy ze względu na jego masowy nakład i nadal powszechne występowanie w księgozbiorach bibliotecznych.

39 A. Nadolski, Grunwald 1410, Warszawa 1993; E. Potkowski, Grunwald 1410. Dzieje narodu i państwa polskiego, Kraków 1994. 
ne książeczki adresowane do dzieci w wieku szkolnym ${ }^{40}$, ale też Krzyżacy 1410 autorstwa Józefa Ignacego Kraszewskiego ${ }^{41}$ i parę dziesiątków innych jeszcze utworów literackich ${ }^{42}$. Swoistą opowieść o wielkiej sugestywności stanowi nadal dzieło Henryka Sienkiewicza, zespolone z ekranizacją z 1960 r. ${ }^{43}$ Ogólne zasady nauczania podpowiadają, w jaki sposób przemówić do dzieci ${ }^{44}$ i jakiego rodzaju uczniowskich opowieści można w zamian oczekiwać, w tym punkcie Podstawa programowa nie odgrywa jednak żadnej instruktywnej roli. Ponieważ wcześniej milczy ona o Krzyżakach (gdyż na etapie szkoły podstawowej jest zbudowana z oderwanych epizodów, bez zachowania ciągłości i wzajemnych związków), zapewne tu właśnie musi zmieścić się jakieś kwantum wiedzy o zakonie jako praprzyczynie bitwy. Jaki ma być jej zasób? O tym znów zadecydują autorzy podręczników. Czy podawać funkcje i imiona zakonnych dostojników poległych w bitwie (przynajmniej samego mistrza Ulryka von Jungingena), czy też uznać to za zbędny balast? O gimnazjaliście w punkcie 14.3 Podstawy programowej napisano: „[uczeń] porządkuje i sytuuje w czasie najważniejsze wydarzenia związane z relacjami polsko-krzyżackimi w epoce Piastów”. Najważniejsze

40 Spośród wielu przykładów podajmy zbeletryzowaną opowieść A. Koskowskiego, Pod murami Malborka, Warszawa 1985, ss. 64, nakład: 40000 egz.

41 J. I. Kraszewski, Krzyżacy 1410. Obrazy z przesztości (pierwodruk miał miejsce w 1882 r., kilkukrotne wznowienia ukazały się po drugiej wojnie).

42 Tytułem przykładu: fabrykujący proste fabuły historyczne dla dzieci Walery Przyborowski zrelacjonował wypadki wielkiej wojny w powieści Grunwald. Swego czasu poczytna była powieść dla młodzieży Grunwaldzkie miecze autorstwa Włodzimierza Barta (był to literacki pseudonim Stefana M. Kuczyńskiego), trzykrotnie wydawana przez LSW w masowych nakładach, podobnie jak cykl powieści Kazimierza Korkozowicza (Przytbice i kaptury, Nagie ostrza), wielokrotnie wznawianych (aż do schyłku lat osiemdziesiątych XX w.) przez Ministerstwo Obrony Narodowej. Na podstawie tego cyklu nakręcono w 1985 r. serial telewizyjny Przytbice i kaptury. Abstrahując od wartości literackiej tej beletrystyki, nie sposób odmówić jej wpływu na świadomość historyczną młodocianych czytelników i widzów.

${ }^{43}$ M. Kosman, Na tropach bohaterów „Krzyżaków”, Poznań 2010.

44 „Do ucznia trzeba przemawiać faktami obfitującymi w barwne szczegóły, poruszającymi wyobraźnię i wywołującymi pożądane napięcia emocjonalne. [...] Operowanie skrótami, formułami ogólnymi, naśladowanie narracji uniwersyteckiej do niczego dobrego w szkole nie prowadzi”, cyt. za: J. Maternicki, Historia jako dialog: studia i szkice historiograficzne, Warszawa 1990, s. 92. 
jest samo przybycie Krzyżaków do Polski (najpierw uzyskali od Henryka Brodatego nadania na Śląsku) i następnie ich umocnienie się w ziemi chełmińskiej i w Prusach, ale czy należy trwale wiedzieć, który książę ich sprowadził, kiedy ${ }^{45}$ i dlaczego oraz co działo się dalej? Należałoby przedstawić budowę państwa krzyżackiego jako wymykający się czarno-białym schematom proces polityczno-cywilizacyjny. Czy opisywać krucjaty krzyżackie, które dzięki zbrojnemu udziałowi europejskich monarchów i krzyżowców (również Piastów i polskich rycerzy) doprowadziły do zbudowania władztwa zakonnego w Prusach? Czy też zadowolić się zdawkowym poinformowaniem o „podbiciu Prusów”? Co prawda nie wyjaśni to genezy nazwy Królewca, ale czy założenie Królewca musi być „uporządkowane i usytuowane”, bo jest „najważniejsze”? Zapewne za takowe jest powszechnie uznane opanowanie przez zakon Pomorza Gdańskiego. Jaki poziom szczegółowości ma jednak osiągnąć podręcznik, skoro Podstawa programowa nie wspomina o Marchii Brandenburskiej (nazwa Brandenburgii w ogóle nie pada w Podstawie programowej w żadnym miejscu i kontekście, skąd może płynąć wniosek skrajny, że uczyć o niej nie trzeba)? Autorzy podręczników muszą więc rozstrzygać, czy roszczenia margrabiów do Pomorza, ich najazd, układy zakończone transakcją z Krzyżakami mają stać się przedmiotem nauczania. Co z atakiem na Kujawy, bitwą pod Płowcami, procesami i pokojem kaliskim? Czy trzeba o nich w ogóle wiedzieć, a jeśli tak, to z jaką dokładnością? Czy zapamiętywać, w jakich latach zaszły, jakie zabiegi dyplomatyczne i mediacje im towarzyszyły, jaka była w nich rola papiestwa, Luksemburgów i Andegawenów? Podobne wątpliwości nastręcza punkt 15.2 (już bezpośrednio dotyczący Grunwaldu), w którym stwierdza się: „[uczeń] porządkuje i sytuuje w czasie najważniejsze wydarzenia związane z relacjami polsko-krzyżackimi w epoce Jagiellonów”. Tym razem zastanówmy się nad znaczeniem czasownika „porządkować”. Wydaje się, że

45 Sam „moment sprowadzenia Krzyżaków do Polski” jest dyskusyjny: kwestionowana już od pewnego czasu data 1226 r. wciąż jednak pojawia się w podręcznikach. Ścisłe ustalenie dat jest utrudnione na skutek zastosowania antydatowań (niektórzy badacze sugerują nawet fałszerstwa) w dokumentach utwierdzających prawa Krzyżaków. Formalne nadanie księcia Konrada nastąpiło raczej w 1228 r., a faktyczne pojawienie się oddziału rycerzy zakonnych dopiero około 1230 r. Właściwiej byłoby mówić o stopniowym napływaniu Krzyżaków na ziemie polskie niż o jednorazowym i ściśle datowanym akcie. 
chodzi o układanie ciągów chronologicznych i przyczynowo-skutkowych. Skoro jednak w monografiach i syntezach materia została już uładzona i należy się spodziewać, że w podręcznikach ten porządek nie zostanie zaburzony - to uczniowi pozostanie tylko zapamiętanie i odtworzenie tych struktur. Odnosimy wrażenie, że zawiłości języka Podstawy programowej kamuflują tylko odwieczne wymogi opanowywania tego, co nauczyciel uzna za właściwe egzekwować ${ }^{46}$.

I na tych wahaniach zakończy się powszechna edukacja historyczna dotycząca Grunwaldu, gdyż na etapie szkoły ponadgimnazjalnej znaczna część uczniów już z tym tematem zupełnie się nie zetknie. Wreszcie na licealnym poziomie rozszerzonym (tylko dla klas profilowanych humanistycznie) figuruje w punkcie II.7.4 zapis: „[uczeń] charakteryzuje i ocenia stosunki polsko-krzyżackie na płaszczyźnie politycznej, gospodarczej i kulturowej”. Każdy akapit nowoczesnej monografii naukowej ${ }^{47}$ pokazuje, że zapis ten - wraz ze wszystkimi poprzednimi - jest równie pojemną instrukcją do budowania szkolnego kursu nauczania, jak nieograniczona powiedzmy bezkresna z definicji - jest „płaszczyzna”.

Warto jeszcze uświadomić sobie, że cezury czasowe dla poszczególnych lat kursu gimnazjalnego nie zostały ustalone. Mamy równocześnie takie serie wydawnicze, w których podręczniki dla pierwszej klasy kończą się na 1138 r., i takie, które zostały zamknięte datą 1492 r. Jeśli mobilność społeczna będzie w Polsce narastać i wzrośnie liczba dzieci zmieniających miejsce zamieszkania, a więc i szkołę, i zwykle także podręczniki, to pojawi

46 Polemiki wokół takich pryncypiów pobrzmiewają jeszcze w literaturze dydaktycznej; por.: K. Kruszewski, 45 minut. Prawie cata historia pewnej lekcji, Warszawa 1993; przeciwko koncepcji Kruszewskiego opowiedział się Józef Półturzycki: „zakłamań, przekręceń i przemilczeń, które zniekształcają temat Grunwaldu jest więcej w podręcznikach oraz w pracy, która [...] jest poświęcona jednej lekcji o charakterze powtórzeniowym w klasie maturalnej, a poświęconej właśnie Grunwaldowi”, J. Półturzycki, Klęska Grunwaldu na lekcji, Toruń 1997, s. 7.

${ }^{4}$ Jako przykłady złożoności badań nad wielką wojną i niejednoznaczności uzyskiwanego obrazu niech posłużą książki: S. Ekdahl, Grunwald 1410. Studia nad tradycją i źródtami, przeł. M. Dorn, Kraków 2010 oraz najnowsza monografia: S. Jóźwiak, K. Kwiatkowski, A. Szweda, S. Szybkowski, Wojna Polski i Litwy z zakonem krzyżackim $w$ latach 1409-1411, Malbork 2010. 
się realny problem uczniów z luką programową na bagatelne trzy i pół wieku historii.

Zaproponujmy pewną grę decyzyjną pod tytułem „Zostań rzeczoznawcą MEN”. Hipotetyczny AUTOR X, piszący podręcznik pod hipotetycznym tytułem „Historia dla rozsądnych minimalistów między pierwszą a drugą klasą gimnazjalną" na zlecenie hipotetycznego Wydawnictwa RYZYKANT i S-ka z o.o., tworzy następujący podrozdzialik:

„Latem 1410 roku na terytorium państwa krzyżackiego wtargnęły połączone wojska polsko-litewskie i ruszyły w kierunku jego stolicy. Armia krzyżacka zastąpiła im drogę w okolicach miejscowości Grunwald. W bitwie strona polsko-litewska, mając wyraźną przewagę liczebną, odniosła zdecydowane zwycięstwo. Wojska krzyżackie przestały stanowić zorganizowaną siłę, zdolną do stawiania oporu w otwartym polu".

Zadanie dla graczy polega na udzieleniu, po gruntownym namyśle, odpowiedzi na pytania:

- Czy uznajesz ten fragment za spełniający wymogi Podstawy programowej (przy założeniu, że wcześniejsze akapity wyjaśniają prawidłowo przyczyny wybuchu wojny, a następne jej skutki)?

- Czy stosując kryteria merytoryczno-rzeczowe, dydaktyczne lub ideowo-wychowawcze, niezależne od Podstawy programowej, decydujesz się uznać ten fragment za nieodpowiedni, niewystarczająco szczegółowy?

- Czy jako nauczyciel praktyk wybrałbyś podręcznik utrzymany w podobnym stylu?

- Sformułuj dla MEN uzasadnienie swej opinii, aby mogło podjąć decyzję o dalszych losach książki.

Po rozegraniu naszej minigry decyzyjnej powróćmy do krainy wydawnictw realnych. Trudno byłoby przeprowadzić kompletną analizę zawartości merytorycznej wszystkich obowiązujących obecnie podręczników gimnazjalnych, nawet w zakresie zawężonym do jednego tematu. Spróbujmy zatem nasze rozważania zilustrować sondażowymi porównaniami, przeprowadzonymi na przykładzie następujących podręczników:

1. Lech Moryksiewicz, Maria Pacholska, Wiesław Zdziabek, Historia 1. Poznajemy przesztość. Starożytność i średniowiecze, SOP Oświatowiec, Toruń 2009, (nr dopuszczenia 186/1/2009); 
2. Tomasz Małkowski, Jacek Rześniowiecki, Historia II. Podręcznik dla klasy II gimnazjum, Gdańskie Wydawnictwo Oświatowe, Gdańsk 2010 (nr dopuszczenia 158/2/2010);

3. Stanisław Roszak, Śladami przeszłości. Podręcznik do historii dla klasy drugiej gimnazjum, Wydawnictwo Nowa Era, Straszyn 2010 (nr dopuszczenia 60/2/2010);

4. Zofia Bentkowska-Sztonyk, Edyta Wach, Historia. Cztowiek i jego cywilizacja, podręcznik dla klasy drugiej, Wydawnictwo Edukacyjne Wiking, Wrocław 2010 (nr dopuszczenia 222/2/2010);

5. Ryszard Kulesza, Stefan Ciara, W kalejdoskopie dziejów, podręcznik do historii. Starożytność. Średniowiecze, gimnazjum klasa 1, Wydawnictwo JUKA, Warszawa 2009 (nr dopuszczenia 160/1/2009);

6. Grzegorz Kucharczyk, Paweł Milcarek, Marek Robak, Historia. Przez tysiaclecia $i$ wieki, gimnazjum klasa 2, Wydawnictwa Szkolne i Pedagogiczne SA, Warszawa 2010 (nr dopuszczenia 61/1/209);

7. Krzysztof Kowalewski, Igor Kąkolewski, Anita Plumińska-Mieloch, Bliżej historii, gimnazjum klasa 1, Wydawnictwa Szkolne i Pedagogiczne SA, Warszawa 2009 (nr dopuszczenia 61/1/2009).

Wybierzmy odpowiednie fragmenty dotyczące koncentracji armii królewskiej i sprzymierzonych wojsk Wielkiego Księstwa Litewskiego, która nastąpiła na prawym brzegu Wisły. Rycerstwo koronne sprawnie przekroczyło rzekę po moście łyżwowym (anachronicznie zwanym pontonowym) spławionym z okolic Sandomierza aż do Czerwińska, gdzie go zmontowano. Według świadectwa Jana Długosza wieści te zostały przyjęte z niedowierzaniem przez wielkiego mistrza. Rozmach i innowacyjność polskiej operacji jest jednym z najchwalebniejszych epizodów kampanii 1410 r.

W podręczniku nr 1 (SOP) wzmianka na ten temat brzmi następująco:

Władysław Jagiełło ruszył w kierunku Malborka, czym zaskoczył Krzyżaków, sądzili oni bowiem, że zaatakuje Gdańsk. W okolicach Czerwińska wojska polskie połączyły się z wojskami litewskimi. Wykorzystano przy tym most pontonowy (s. 221). 
W tej narracji pojawia się: zaskakujący atak na stolicę zakonu (zamiast na Pomorze), umiejscowione połączenie wojsk oraz most. Opowieść musi być jednak uzupełniona umiejętnym odczytaniem stosownej mapy, której w tym podręczniku nie ma. Czerwińsk nie jest miejscowością, którą gimnazjaliści automatycznie skojarzą z Wisłą. Potrzeba zbudowania mostu, nowatorstwo i skala tego przedsięwzięcia nie są skomentowane. Podane fakty bez objaśnień ze strony nauczyciela nie są wystarczająco wymowne.

W podręczniku nr 2 (GWO) faktografia jest podobna, ale rozpatrywany fragment dłuższy:

\begin{abstract}
W początku lipca 1410 roku Polacy przekroczyli Wisłę po drewnianym moście pontonowym, jakiego nigdy pierwej nie widziano. $\mathrm{Na}$ prawym brzegu rzeki połączyli się z Litwinami. Obie armie pomaszerowały prosto na Malbork. Kierunek uderzenia zaskoczył wielkiego mistrza. Ulrich von Jungingen spodziewał się wojny raczej na Pomorzu Gdańskim. Armia krzyżacka pospiesznie ruszyła spod Chełmna na wschód, by chronić stolicę (s. 93).
\end{abstract}

Kolejność następujących po sobie faktów jest logiczna, a kilka trafnych okoliczników i cytat uczyniły narrację obrazową. Tekst nie narzuca wniosku, ale pozwala zrozumieć (nadal bez mapy!), po co był potrzebny ów nadzwyczajny most i do czego zmusił wielkiego mistrza manewr wojsk polsko-litewskich. Autorzy zrezygnowali z nazywania miejsca przeprawy, wprowadzając za to (czy potrzebnie?) Chełmno, jako punkt dyslokacji wojsk krzyżackich. Niepokoi podanie w tym miejscu i w ten sposób (po raz pierwszy) imienia wielkiego mistrza. Słabo czytający uczeń może mieć kłopot z identyfikacją postaci i zagubić się w tym miejscu.

Zupełnie inaczej dobrano fakty i osnuto analogiczną opowieść w podręczniku nr 3 (Wyd. Nowa Era). Jest to tym ciekawsze, że temat wielkiej wojny został potraktowany w tej książce szeroko i dogłębnie. Narracja opiera się głównie na opisie planowania strategicznego strony polsko-litewskiej (tajna narada Jagiełły z Witoldem, oznaczenie kierunku natarcia i miejsca koncentracji pod Czerwińskiem nad Wisła). Narrację wspiera właściwa mapa, ale zniknął z niej zupełnie most (s. 94-95). 
W podręczniku nr 4 (Wyd. Wiking) elementy powracają do poprzedniej „normy” (przy czym autorki wcześniej piszą sporo o zapobiegliwych przygotowaniach aprowizacyjnych Jagiełły):

W największej tajemnicy budowano części składowe mostu do szybkiej przeprawy przez Wisłę. Koncentracja wojsk polskich i litewskich nastąpiła pod Czerwińskiem. W pobliżu tej miejscowości wojska przeszły na drugi brzeg Wisły po skonstruowanym wcześniej moście. [...] Połączone wojska kierowały się na Malbork, stolicę państwa zakonnego. Przeciw polskiemu i litewskiemu wojsku wyszło rycerstwo zakonne (s. 16).

Z tej opowieści dowiadujemy się o planowym i tajnym budowaniu składanego mostu, ale nie o istocie jego konstrukcyjnego novum i zaskoczeniu, jakie wywołało u przeciwnika. Dalej zaś narracja błędnie sugeruje, że połączenie wojsk nastąpiło przed przeprawą, podczas gdy tylko armia koronna musiała przejść na prawy brzeg rzeki, na którym Litwini już byli, maszerując po prawej stronie Bugu. Znowu konieczne będzie więc użycie „pozapodręcznikowej” mapy i korekta opisu ze strony nauczyciela.

Rozwiązanie przyjęte w podręczniku nr 5 (wyd. JUKA) jest najbardziej zaskakujące, gdyż opis kampanii 1410 r. ogranicza się do samej tylko bitwy grunwaldzkiej (s. 238). Przygotowania logistyczne i manewry strategiczne zostały tu całkowicie pominięte.

Podręcznik nr 6 (WSiP) zawiera znowu „kanoniczny” zestaw faktów:

Przebieg kampanii był następujący. Najpierw wojska polsko-litewskie pozorowały marsz na Pomorze, po czym nagle, w czerwcu 1410 r., przeszły Wisłę pod Czerwińskiem po moście pontonowym (to znaczy zbudowanym na łodziach) i wkroczyły do państwa zakonnego. Do wojsk polskich dołączył wielki książę Witold z siłami litewskimi oraz posiłkami ruskimi i tatarskimi. Armia polsko-litewska skierowała się na stolicę państwa krzyżackiego - Malbork (s. 28).

Narracja jest tym razem syntetyczna. Wyjaśniono, jak był zbudowany most, ale zaledwie zasygnalizowano strategiczne znaczenie użycia go do „nagłego" przejścia Wisły. Skróty myślowe, oczywiste dla historyków, odbiorcę niewyrobionego mogą wprawić w zakłopotanie. Mylne jest użycie w drugim zdaniu wyrażenia „wojska polsko-litewskie”, bo tylko wydzie- 
lone oddziały rycerstwa polskiego prowadziły dezorientujące Krzyżaków działania na pograniczu pomorskim i tylko wojska polskie przeprawiały się po moście. Wewnętrzna sprzeczność ujawnia się w zdaniu trzecim, kiedy okazuje się, że Litwini połączyli się z armią królewską później. W dodatku sugeruje się, że ta koncentracja nastąpiła już na terenie państwa zakonnego, a przecież doszło do niej przed wkroczeniem w jego granice. Tajemniczo brzmią „posiłki ruskie” - tak jakby nadeszły z innego państwa. Bez wyjaśnień nauczyciela tekst pozostanie niekonsekwentny i może prowadzić do błędnych wniosków, tym bardziej że znowu brakuje odpowiedniej mapy.

Podręcznik nr 7 (także WSiP) przynosi obraz złożony z podobnych faktów, ale inaczej zinterpretowanych:

Król Władysław Jagiełło poprowadził ofensywę wojenną bardzo rozważnie. Zgromadził najliczniejszą w średniowieczu armię rycerstwa polskiego [...]. Przeprawił swoje wojska przez Wisłę po moście pontonowym pod Czerwińskiem, połączył z litewską armią księcia Witolda i ruszył na Malbork, stolicę państwa krzyżackiego (s. 236-237).

W tym ujęciu zaakcentowano rozwagę króla, ale zagubiono element planowania strategicznego i zaskakującego kierunku polsko-litewskiego uderzenia. Konkludując: uczeń dowie się, że zbudowano most, ale nie zauważy, że było to pionierskie osiągnięcie inżynierii wojskowej, dzięki któremu z imponującą prędkością udało się połączyć wojska sprzymierzonych.

Powyższy przegląd ujawnił, że narracja w większości podręczników została zbudowana z identycznych lub bardzo podobnych elementów. Nie wydaje się jednak, by wynikało to z pogłębionej refleksji nad rangą wplecionych w nią faktów i znaczeniem użytych słów i zwrotów. Decydowało raczej przyzwyczajenie, uleganie tradycji, której źródeł w tym momencie nie będziemy dociekać. Być może biją one w jakimś klasycznym (leciwym?) ujęciu polskiej historiografii. Ponieważ jednak Podstawa programo$w a$, jak to wyżej pokazaliśmy, daje instrukcje ogólnikowe i mgliste, autorzy dwóch podręczników dobrali do swej narracji o kampanii grunwaldzkiej inne wątki albo wydatnie ją skrócili i nie można im czynić z tego powodu wyrzutów.

Jeszcze raz zagrajmy w „Rzeczoznawcę MEN”. Hipotetyczny AUTOR Y, piszący podręcznik pod hipotetycznym tytułem „Myśl o przeszłości dla 
przyszłości, pomiędzy pierwszą a drugą klasą gimnazjalną” na zlecenie hipotetycznego Wydawnictwa „Takie będą Rzeczypospolite... etc.”, tworzy następujący podrozdzialik:

„Polsko-litewscy sprzymierzeńcy precyzyjnie zaplanowali kampanię 1410 roku. Do orszaku Władysława Jagiełły wędrującego z Krakowa ku północy, w wyznaczonych miejscach dołączało rycerstwo z kolejnych krain i ziem ${ }^{48}$ Polski. (Zadanie w pobocznej ramce: Na podstawie mapki ustal nazwy tych ziem i krain historycznych Polski. Dlaczego walecznych rycerzy z okolic Nowego Sącza król nie zabrał ze sobą na wyprawę wojenną w odległe strony?) Zebrawszy armię nieopodal granic państwa krzyżackiego, król przeprawił ją z lewego na prawy brzeg Wisły. Użył do tego pływającego, drewnianego mostu. Zbudowano go zawczasu potajemnie w puszczach pod Sandomierzem, spławiono w częściach w dół rzeki i złożono w całość w miejscu przeprawy. Wielki mistrz nie mógł uwierzyć, że Polacy tak sprawnie pokonali trudną przeszkodę, jaką była w owych czasach szeroka rzeka. Wcześniej nie budowano w tych stronach mostów na łodziach. (Zadanie w pobocznej ramce: Jak nazywa się tego typu most? Dowiedz się lub przypomnij sobie, w jakich okolicznościach używa się współcześnie podobnych konstrukcji). Na prawym brzegu Wisły punktualnie pojawiły się też wojska Wielkiego Księstwa Litewskiego, prowadzone przez Witolda. Sprzymierzeni razem skierowali się na Malbork, gdy tymczasem Krzyżacy oczekiwali raczej ataku na Pomorze Gdańskie”.

48 Zakładamy, że na mapce będą uwidocznione nazwy głównych krain historycznych, jak Ruś, Małopolska, ziemia sandomierska, Wielkopolska, Kujawy i Mazowsze, oraz schematyczne szlaki wędrówki rycerstwa dołączającego do głównego korpusu królewskiego, a także rejon koncentracji rycerzy ziemi sądeckiej, którzy mieli ochraniać południową granicę przed inwazją Zygmunta Luksemburskiego. Na mapie musiałyby być także oznaczone kraje sprzymierzone z zakonem lub popierające jego politykę. Wcześniej byłyby wprowadzone pojęcia „ziemia” i „kraina historyczna”, a także utrwalane systematycznie ich nazwy i położenie. W ten sposób zadania zostałyby wkomponowane w cały system ćwiczeniowy podręcznika. 


\section{Zadania końcowe:}

1) Wyobraź sobie, że jesteś polskim rycerzem z okolic Tarnowa i jeszcze nigdy nie widziałeś Wisły w jej dolnym biegu. Co myślałbyś, forsując w bród wielką rzekę? Jakie niebezpieczeństwa by $\mathrm{Ci}$ grozily? Oceń znaczenie przeprawy mostowej dla kondycji wojsk polskich.

2) Wyobraź sobie, że jesteś świeckim rycerzem pruskim zobowiązanym do służby w szeregach wojsk zakonu krzyżackiego. Jak na Twoją odwagę wpłynęłaby wiadomość o sprawności ofensywnej przeciwnika?

Dobór składowych faktów, ich powiązań, związków przyczynowo-skutkowych, frazeologii, terminologii, słownictwa, stylu oraz podjęcie prób bieżącego aktywizowania uczniów przez odniesienia do mapki (stanowiącej absolutnie niezbędne i koniecznie powiązane $\mathrm{z}$ tekstem uzupełnienie) wynikają tym razem z przekonania, że koncentracja rycerstwa polskiego to zagadnienie godne wyeksponowania, o szerokich walorach poznawczych i kształcących - zdecydowanie większych niż opis samej bitwy ${ }^{49}$. Odpowiedzi na pytania końcowe wchodzą w sfery spekulacji, a może nawet historii alternatywnej, ale jest to chyba warunek problemowego nauczania historii. Jeśli zaś, czy to samodzielnie, czy wspólnie z klasą i nauczycielem, gimnazjaliście uda się je sformułować, to most, „jakiego nigdy pierwej nie widziano" (pomijając jego lokalizację pod Czerwińskiem), okaże się istotnym czynnikiem podnoszącym morale jagiełłowego rycerstwa, a umniejszającym krzyżacką pewność siebie. Stanie się przydatny dydaktycznie.

Proponowana redakcja hipotetycznego AUTORA Y okazała się jednak kilkakrotnie dłuższa od fragmentów uprzednio przytoczonych, zatem konsekwentne uprawianie tego sposobu narracji albo rozsadziłoby rozsądne normy objętości podręcznika, albo zmusiłoby do ostrej selekcji rozwijanych

49 Podręcznikowe opisy bitwy pod Grunwaldem słabo odzwierciedlają rozliczne wątpliwości towarzyszące badaczom usiłującym ją zrekonstruować. Liczebność wojsk, wysokość strat, usytuowanie stanowisk wyjściowych, uszykowanie i taktyka walczących formacji, jak też zasługi dowódcze wybitnych uczestników bitwy nie są ustalonymi pewnikami, tylko hipotezami, wciąż stanowiącymi przedmiot rewizji, polemik i sporów. 
wątków. Lakoniczny opis z podręcznika nr 1 (SOP) pozwolił autorom tej dwustupięćdziesięciostronicowej książki z cezurą końcową 1492 r. przytaczać przy wielu okazjach pomijane przez innych fakty, jak np. nabycie Nowej Marchii - znamienny przejaw terytorialnych aspiracji zakonu u progu XV w. (s. 219). Nie istnieje jednak prosta zależność między bogactwem faktografii a jakością ostatecznego efektu.

Powyższe rozważania nie są oderwane od realiów egzaminacyjnych. Arkusz Egzaminu w klasie trzeciej gimnazjum z zakresu przedmiotów humanistycznych, użyty w kwietniu 2010 r., zawierał pięć zadań (od 7 do 11) opartych na odczytaniu i przeanalizowaniu fragmentu Krzyżaków Henryka Sienkiewicza (scena uwalniania pojmanego Zygfryda de Loewe przez Juranda). Dwa dalsze zadania (nr 12 i 13) były powiązane z tym tekstem już tylko przez tło dziejowe i wymagały użycia wiedzy z zakresu historii. Najprościej będzie je przytoczyć:

\section{Zadanie 12. (za 1 punkt)}

W XIII i XIV w. państwo krzyżackie rozwinęło się głównie w następstwie

A. zawarcia przymierza między Zakonem i Stolicą Apostolską.

B. ekspansji Krzyżaków na terytorium Prusów oraz ziemie polskie i litewskie.

C. pokojowych negocjacji Krzyżaków z książętami piastowskimi Pomorza.

D. oddania się mieszkańców Prus i terenów z nimi graniczących pod opiekę Krzyżaków.

\section{Zadanie 13. (za 1 punkt)}

Krzyżacy byli zakonem
A. rycerskim.
B. żebraczym.
C. pustelniczym.
D. kontemplacyjnym. 
Zadania te wyglądają na łatwe, a prawidłowe odpowiedzi są oczywiste - dla ewentualnych czytelników tego tekstu. Czy takimi były dla każdego gimnazjalisty? ${ }^{50}$

W arkuszu z 2008 r. banalne zadanie nr 8, w którym należało wybrać spośród czterech podanych możliwości odpowiedź na pytanie, z jakiej dynastii wywodził się Bolesław Krzywousty, potrafiło rozwiązać zaledwie 49\% egzaminowanych, mimo że „swego rodzaju podpowiedź była zawarta w przypisie" do fragmentu Kroniki Anonima, w którym podano lata życia tego władcy ${ }^{51}$. Postać Bolesława z całą pewnością nie została pominięta $\mathrm{w}$ żadnej z gimnazjalnych serii podręczników i wystąpiła w czytelnym powiązaniu z okresem panowania dynastii piastowskiej. Czy nauczanie według nowej Podstawy programowej (przywołującej postać Bolesława III w punkcie 14.2) sprawi, że rozpoznanie go jako Piasta przestanie przerastać połowę spośród przeciętnie uzdolnionych uczniów? Gimnazjalistów egzaminowanych w 2008 i 2010 r. obowiązywała jeszcze poprzednia Podstawa programowa, ale przecież z „języka wymagań” nowej także wyodrębnia się wątki, z których utkana jest narracja historyczna i które stają się składnikami zadań egzaminacyjnych. Obydwa zadania o Krzyżakach z 2010 r. mieszczą się prawdopodobnie w zakresie rozpatrywanych zapisów o relacjach między Polską a zakonem, ale trudno o tym przesądzać. Niemal każde odniesienie do wiedzy uszczegółowionej - czy to w podręczniku, czy w narzędziu pomiaru dydaktycznego - w świetle poddanych analizie punktów Podstawy programowej może być uznane za właściwe lub zakwestionowane, w zależności od jej interpretacji. Dyskusyjne pozostaje, jakim zasobem faktów, pojęć i wyobrażeń ma rozporządzać absolwent etapu gimnazjalnego zanim przystąpi do ich prawidłowego porządkowania, hierarchizowania, a wreszcie - syntetyzowania. Zatem „istotne uściślenie” zakresu nauczania, jakie według MEN-u przyniosła nowa Podstawa programowa, wydaje się

${ }^{50}$ W raporcie Centralnej Komisji Egzaminacyjnej z 2010 r. nie udało się autorowi odszukać wyników poszczególnych zadań.

${ }^{51}$ Dystraktory tego zadania nie były podchwytliwe, a jednak: dynastię Jagiellonów wybrało 37\%, Wazów 10\%, Sasów 3,6\%; „Zadanie odwoływało się do znajomości kontekstu historycznego niezbędnego do interpretacji tekstów kultury”, cyt. za: Osiagnięcia uczniów kończących gimnazjum $w$ roku 2008. Sprawozdanie z egzaminu gimnazjalnego 2008, Centralna Komisja Egzaminacyjna, Warszawa [b.r.], s. 88. 
iluzoryczne. Gdyby zaś wiedza przyswojona (m.in. z podręczników) miała być sprawdzana na egzaminie, to zauważmy, że nawet z okrojonego chronologicznie materiału takich nieprzesadnie dogłębnych zadań da się ułożyć z pewnością kilkaset, a może i kilka tysięcy.

Powyższe wywody i wnioski nie zmierzają do jałowej krytyki Podstawy programowej lub ataku na zespół, który ją formułował, niewątpliwie w dobrej wierze. Nie postulujemy bynajmniej narzucenia szkolnictwu jednolitego, rozwiniętego do najdrobniejszych szczegółów programu ani też jednego, jedynie słusznego podręcznika ${ }^{52}$. Na powyższych przykładach demonstrujemy jedynie, że rozstrzygnięcia w sprawie treści nauczania, tak jak poprzednio, spoczywają w pierwszym rzędzie na autorach podręczników ${ }^{53}$. Formułka figurująca na okładkach ukazujących się aktualnie książek: „zgodne z nową Podstawa programowa" o ich zawartości nie mówi w istocie niczego. Ocenianie ich przez konfrontację z zasadniczym dokumentem normatywnym MEN-u nie prowadzi do żadnych konkluzji o charakterze jakościowym. Po reformatorskiej operacji przynajmniej dwa wydawnictwa uzyskały zatwierdzenia MEN-u dla poprzednio już znanych podręczników gimnazjalnych, dokonując tylko zmian materiału ilustracyjnego, szaty graficznej i podziału na tomy, ale nie korygując narracji autorskich.

Każdemu z elementów podręcznika do historii oraz ich wzajemnym relacjom wypadałoby poświęcić osobne studium analityczne ${ }^{54}$.

52 Urzędnicy MEN obiecują wprowadzenie w 2015 r. 18 bezpłatnych e-podręczników do „wszystkich podstawowych przedmiotów nauczania” (nasłuch I Programu Polskiego Radia w dniach 20-21 sierpnia 2013 r. audycja Sygnaty dnia w godzinach 6.306.50.) Dyskusja radiowa dotyczyła kosztów wyposażenia dzieci przed nowym rokiem szkolnym. Przy okazji nie zauważono, że rynek podręczników używanych został rozregulowany właśnie na skutek decyzji MEN i konieczności dostosowania wydawnictw szkolnych do nowej Podstawy programowej oraz wyrzucenia na makulaturę milionów zdatnych jeszcze do użytku egzemplarzy książek. Niewątpliwie zajmującym problemem z zakresu ekonomiki, polityki edukacyjnej, prawa oświatowego i - rzecz jasna - dydaktyki będzie sposób, w jaki Ministerstwo wprowadzi e-podręczniki, które prawdopodobnie zachwieją tradycyjnym rynkiem księgarskim w Polsce.

53 E. Chorąży, D. Konieczka-Śliwińska, S. Roszak, op. cit., s. 167.

54 Ogólną typologię podręczników zestawiają F. Bereźnicki, Podstawy ksztatcenia ogólnego, Kraków 2011, s. 77-79; M. Bieniek, op. cit., s. 74; problemy dyskusyjne omówił J. Maternicki, Szkolne podręczniki historii, s. 125-134; jako przykłady analizy zagad- 
Pierwszorzędnym kryterium oceny pozostanie jednak zawsze zawartość merytoryczna. Książki, która nie będzie poprawna pod tym względem, nie da się zaakceptować, choćby była najpiękniejsza i najcelniejsza dydaktycznie. Podręczniki nie powinny szerzyć wiedzy niezweryfikowanej lub zakwestionowanej dzięki postępowi badań, infantylizować i nadmiernie spłycać narrację, wprowadzać w błąd zbytnimi uproszczeniami, zachwianiem proporcji zjawisk lub niefrasobliwym doborem faktów. Inna sprawa - i to wysoce dyskusyjna - jak czuwać nad ich poprawnością, jakie procedury lub restrykcje powinny mieć zastosowanie w tym względzie ${ }^{55}$. Kolejne recenzje przedstawiane Komisji Polskiej Akademii Umiejętności do Oceny Podręczników dotyczące nowych podręczników gimnazjalnych pokazują, że aktualnie stosowane przepisy nie są skuteczne. Zatwierdzenia MEN-u otrzymały także książki z relatywnie znaczną liczbą potknięć i omyłek ${ }^{56}$.

nień cząstkowych: G. Chomicki, Kilka uwag na temat miejsca tekstów źródtowych w nowych podręcznikach historii, [w:] Przesztość w szkole przysztości, red. J. Walczak, A. Zielecki, Częstochowa 1997, s. 191-194; T. Maresz, Przegląd podręczników do historii w liceum pod kątem zawartych $w$ nich fragmentów źródet pisanych, [w:] Historia, dydaktyka, media, red. B. Tarnowska, Bydgoszcz 2002, s. 221-234.

55 Również w Niemczech procedury oceniania podręczników budzą wątpliwości i wywołują kontrowersje, co przedstawił Joachim Rohlfes w przywołanej wyżej pracy. Do gorętszych sporów dochodzi na Litwie i Białorusi: A. Vysniauskas, Skandale podręcznikowe na Litwie, „Wiadomości Historyczne” 2008, nr 3, s. 12-18; I. Kiturka, Niektóre aspekty rozwoju edukacji historycznej w Republice Biatoruś, „Wiadomości Historyczne” 2010, nr 6, s. 24-29.

56 Recenzje są opublikowane w rocznikach czasopisma „Opinie Edukacyjne Polskiej Akademii Umiejętności. Prace Komisji PAU do Oceny Podręczników Szkolnych” 2011, t. 9, gdzie podręczniki dla klasy I gimnazjalnej ocenił P. Rabiej, Opinia o częściach dotyczacych średniowiecza w podręcznikach: Śladami przeszłości. Podręcznik do historii dla klasy pierwszej gimnazjum, pod red. S. Roszaka, Wydawnictwo Nowa Era, Straszyn 2009; T. Matkowski, J. Rześniowiecki, Historia I. Podręcznik dla klasy I gimnazjum, Gdańskie Wydawnictwo Oświatowe, Gdańsk 2010; S. Ciara, Średniowiecze, [w:] W kalejdoskopie dziejów. Podręcznik historii, gimnazjum, klasa 1, Wydawnictwo JUKA, Warszawa 2009; K. Kowalewski, I. Kąkolewski, A. Pluminska-Mieloch, Bliżej historii. Gimnazjum - podręcznik, klasa 1, Wydawnictwo Szkolne i Pedagogiczne, Warszawa 2009; idem, Opinia o częściach poświęconych średniowieczu w podręcznikach do klasy I gimnazjum: J. Trzebniak, P. Trzebniak, Cztowiek i jego cywilizacja, Wydawnictwo Edukacyjne Wiking, Wroctaw 2009; M. Pieńkowska-Koźmińska, Dawno temu, wczoraj, dziś, Wydawnictwo Stentor, Warszawa 2009; G. Kucharczyk, P. Milcarek, M. Robak, Historia. Przez tysiaclecia i wieki, WSiP, 


\title{
The history textbooks in the face of the reform of the education system. The challenges of selecting content
}

\author{
(SUMMARY)
}

At Polish schools textbooks are an important part of the accoutrements of both students and teachers. More often than not the teachers submit to the content of the textbook. Thus one can observe it being used as an informal curriculum.

The fundamental problems of historical education thusly continue to be: the selection, hierarchisation and systematization of the content. It is impossible to teach methodology and research techniques without the background provided by factual information. The criterion for choosing facts should be the continuity of phenomena in modern culture and social reality as well as their presence among the employed codes and the accepted systems of values. The question of the number of terms and phenomena crucial for creating ideas allowing for the understanding of the past constantly returns as a vital problem to be tackled as without resolving it the very usefulness of teaching history becomes dubitable.

The new core curriculum outlines what the textbooks should include, however, it is a relatively terse document which only hints at what the obligatory content is. An analysis of the ministerial document's entries proves that the expectations

Warszawa 2009; L. Moryksiewicz, M. Pacholska, W. Zdziabek, Historia. Poznajemy przesztość, SOP Oświatowiec, Toruń 2009; J. Ustrzycki, Historia, Wydawnictwo Operon, Gdynia 2009. W tomie 10 (Kraków 2012) zamieszczono artykuły recenzyjne M. Ferenca, Uwagi na temat podręczników do historii dla klasy drugiej gimnazjum: 1) Jacka Chachaja i Janusza Droba, Historia. Czasy nowożytne. Podręcznik dla gimnazjum. Klasa II, Warszawa 2010, Wydawnictwa Szkolnego PWN 2) Tomasza Matkowskiego i Jacka Rześniowieckiego, Historia II. Podręcznik dla klasy II gimnazjum, Gdańsk 2010, Gdańskiego Wydawnictwa Oświatowego; 3) Stanistawa Roszaka, Śladami przesztości. Podręcznik do historii dla klasy drugiej gimnazjum, Straszyn 2010, Wydawnictwa Nowa Era; 4) Janusza Ustrzyckiego, Historia 2. Podręcznik dla gimnazjum, Gdynia 2010, Wydawnictwa Pedagogicznego OPERON; idem, Opinia o podręcznikach do historii nowożytnej dla klasy II gimnazjum: S. Ciara, J. Sikorska-Kulesza, W kalejdoskopie dziejów..., Wydawnictwo JUKA, Warszawa 2010; M. Jadczak, M. Meissner-Smota, S. Zając, Historia. Poznajemy przesztość..., Wydawnictwo SOP Oświatowiec, Torun 2010; Z. Bentkowska-Sztonyk, E. Wach, Historia. Cztowiek i jego cywilizacja..., Wydawnictwo Edukacyjne Wiking, Wroctaw 2010; G. Kucharczyk, P. Milcarek, M. Robak, Historia. Przez tysiąclecia i wieki..., WSiP, Warszawa 2010; I. Kąkolewski, A. Plumińska-Mieloch, Bliżej historii..., WSiP, Warszawa 2009. 
towards the content are a complete enigma to the authors of the textbooks. The authors of the core curriculum proclaim a departure from learning encyclopedic knowledge by heart. The student, however, will not be able to acquire higher level skills without using factual information and terms and establishing their own system of ideas. This is why the promises that the core curriculum will provide clear expectations from schools and explain the examination requirements have not been fulfilled.

And overview of selected fragments of seven textbooks has shown that the narration in most of them was built from identical or very similar elements, however, the authors of some of them selected different strands for their book or shortened it considerably. My conclusions are meant to show that the decisions as to the chosen events and the narration, just like earlier, remain in the hands of the textbook authors and the first criterion of evaluating the books is still the factual content.

Grzegorz Chomicki

Instytut Historii, Uniwersytet Jagielloński grzegorz.chomicki@uj.edu.pl 